\title{
Viljatilojen tuottavuuskehitys vuosina 1976 - 2003
}

\author{
Sami Myyrä ${ }^{1)}$ ja Pekka Pihamaa ${ }^{1)}$ \\ ${ }^{1)}$ MTT taloustutkimus Luutnantintie 1300410 Helsinki, sami.myyra@mtt.fi, pekka.pihamaa@mmm.fi
}

\begin{abstract}
Tiivistelmä
Tuottavuus määritellään siksi tuotannon määrän muutokseksi, jota ei voida selittää panosten käyttömäärässä tapahtuneella muutoksella. Maatalouden tuottavuuskehitystä pidetään yhtenä tärkeimmistä maatalouspolitiikan tavoitteista (Valtioneuvoston maatalouspoliittinen selonteko). Yksittäiselle viljanviljelijälle tuottavuuden tasolla ei enää ole niin suurta merkitystä kuin aikaisemmin, sillä viljatilojen liikevaihdosta alle puolet tulee tuotteiden myyntituotoista.

Tässä tutkimuksessa selvitettiin kannattavuuskirjanpidon viljatilojen tuottavuuskehitys vuosina 1976 2003. Tällä ajanjaksolla voimakkain toimintaympäristön muutos oli Suomen liittyminen EU:hun vuoden 1995 alussa. Ennen EU:ta viljatilojen saama tuki sisältyi pääasiassa tuotteiden hintoihin (hintatuki). EU-aikana tuotantoa on tuettu pääasiassa pinta-alaperusteisin tuin. Viljelijän näkökulmasta keskeisin muutos oli panosten rajatuoton olennainen heikkeneminen. Pinta-alaperusteiset tuet ja niihin liittyvät ehdot eivät puolestaan vaikuta hehtaarikohtaiseen panosten käyttöön ja siten tuottavuuteen muutoin kuin joidenkin reunaehtojen kautta.

Tutkimuksen tärkein tavoite oli selvittää viljatilojen tuottavuuskehitys ja siinä ajan myötä tapahtuneet muutokset. Toisena tavoitteena oli selvittää, onko tuottavuuskehityksessä ollut eroja erikokoisilla tiloilla tai eri tukialueilla.

Vuonna 2003 viljatilojen tuottavuuden taso oli 9,7 \% korkeampi kuin vuonna 1977. Tekninen kehitys, jota tarkasteltiin tuotantofunktion neutraalina siirtymänä ajan suhteen, havaittiin tilastollisesti merkitseväksi. Kun 9,7 \%:n tuottavuuskehitystä tarkastellaan 26 vuoden aikaperspektiivissä, voidaan todeta, että tuottavuuskehitys on ollut keskimäärin 0,36 \% vuodessa.

Viljatiloilla havaittava tuottavuuden vuotuinen vaihtelu on suurta. Pitkälti sääolosuhteista johtuva satotason vuotuinen vaihtelu aiheutti tarkasteluajanjaksona itseisarvoltaan keskimäärin $12 \%$ vuotuisen vaihtelun viljatilojen tuottavuuden tasoon. Tulokset osoittavat, ettei suomalaisten viljatilojen tuottavuuskehitystä voi selvittää harhattomasti kovin lyhyellä aikasarjalla. Nyt käytettävissä olevan aikasarjan perusteella näyttää siltä, että viljatilojen tuottavuuskehitys on EU jäsenyyden aikana pysähtynyt. Tuottavuuskehityksen pysähtymistä ei voida kuitenkaan katsoa johtuneen pelkästään taloudellisessa toimintaympäristössä tapahtuneista muutoksista, sillä viljatilojen tuottavuuskehityksessä on havaittavissa hitaita jaksoja aikaisemminkin.

Tukialueittain tarkasteltuna viljatilojen tuottavuuskehitys on ollut lähes identtistä. Tämä havainto pätee sekä EU-jäsenyyden aikana että ennen sitä. Tuloksen perusteella ei voida katsoa, että tukijärjestelmä olisi antanut erilaisia kannusteita tuottavuuden kehittämiseen eri tukialueilla. Kokoluokittain tarkasteltuna tekninen kehitys on ollut tilastollisesti merkitsevästi erilaista erikokoisilla tiloilla ja tästä johtuen tuottavuuskehityskin on myös eroja. Tuottavuuskehitys on ollut suurilla tiloilla nopeampaa kuin pienillä tiloilla.
\end{abstract}

\section{Asiasanat: tuottavuus, viljatilat}




\section{Johdanto}

Tässä tutkimuksessa selvitettiin kannattavuuskirjanpidon viljatilojen tuottavuuskehitys vuosina 1976 - 2003. Kyseisellä ajanjaksolla voimakkain toimintaympäristön muutos oli Suomen liittyminen EU:hun vuoden 1995 alussa. Ennen EU:ta viljatilojen saama tuki sisältyi pääasiassa tuotteiden hintoihin (hintatuki). EU-aikana tuotantoa on tuettu pääasiassa pinta-alaperusteisin tuin. Viljelijän näkökulmasta keskeisin muutos oli panosten rajatuoton olennainen heikkeneminen. Viljanviljelyn tuottavuuskehityksen ylläpitämiseksi ja teknisen kehityksen vauhdittamiseksi otettiin käyttöön investointitukijärjestelmä. Investointitukijärjestelmän tavoitteena on ylläpitää viljelijöiden tulotaso tuottavuus- ja rakennekehityksen avulla yhdessä pinta-alaperusteisten tukien kanssa.

Panosten rajatuoton alenemisesta seurasi kuitenkin se, että sekä lyhyen että pitkän aikavälin tuotannollisten panostusten kannattavuus aleni. Hyviä esimerkkejä tästä ovat lannoitteiden käytön pieneneminen sekä kalkituksen ja salaojituksen olennainen väheneminen. Pinta-alaperusteiset tuet ja niihin liittyvät ehdot eivät puolestaan vaikuta (kannusta) hehtaarikohtaiseen panosten käyttöön ja siten tuottavuuteen muutoin kuin joidenkin reunaehtojen kautta. Tilatasolla pinta-alaperusteisten tukien asettamat reunaehdot saattavat kuitenkin vaikuttaa merkittävästi tilalla viljeltävään kasvilajivalikoimaan.

Maatalouden tuottavuudessa tapahtuvat muutokset ovat hitaita, parhaimmillaankin vain muutamia prosentteja vuodessa. Aikaisempien tutkimusten perusteella tiedetään, että viljatiloilla tuottavuuden taso saattaa vaihdella kuitenkin sääolosuhteista johtuen huomattavastikin (Ylätalo 1987). Yleistettävien tulosten laskeminen lyhyestä aikasarjasta saattaakin siksi olla vaikeaa. Tässä tutkimuksessa käytetty pitkä aikasarja helpottaa trendimäisen tuottavuuskehityksen suhteuttamista tuottavuuden vuotuiseen vaihteluun.

Käytetty tutkimusote, joka perustuu tuotantofunktioiden estimointiin, mahdollisti tuottavuuskehityksen jakamisen skaalatuottoihin ja tekniseen kehitykseen. Lisäksi skaalatuotot ja tuottavuuskehitys määritettiin tiloittain, joten tuloksia voidaan tarkastella niin tilakokoluokittain kuin tukialueittainkin.

\section{Aineisto ja menetelmät}

\section{Aineisto}

Tämän tutkimuksen aineistona käytetään kannattavuuskirjanpidon viljatiloja. Tutkimustilojen valintakriteeriä on tämän lisäksi kiristetty niin, että kolmen vuoden liukuvana keskiarvona tarkasteltuna vähintään $65 \%$ tilojen liikevaihdosta (ilman tukia) on tullut viljan tai öljykasvien myynnistä.

Tutkimus on tehty tilatasolla. Tästä syystä tuotantoa selittävät tuotantopanokset (työ, pääoma ja vuotuiskustannukset) ovat tuotantofunktiossa keskenään korreloituneita. Multikollinearisuuden pienentämiseksi viisi suurinta ja viisi pienintä tilaa poistettiin aineistosta. Näin selittävien muuttujien välinen korreloituneisuus saatiin tiputettua 0,65-0,85 :sta 0,53-0,79:aan. Jäljelle jäänyttä multikorrelaatiota ei voida poistaa, jos tarkastelu halutaan pitää tilatasolla. Siirtymällä hehtaaritason tarkasteluun tämä ongelma poistuisi. Tässä tapauksessa skaalatuoteottojen oletettaisiin kuitenkin olevan 1 . Tätä oletusta ei kuitenkaan haluta tehdä, sillä skaalatuottojen selvittäminen on yksi tutkimuksen tavoitteista.

Tuotannon määrää mitattiin tuotteiden myyntituloilla, eli tuettomalla liikevaihdolla. Koko tuettoman liikevaihdon käyttöön tuotannon määrää kuvaavana muuttujana päädyttiin, sillä on suhteellisen haastavaa jakaa panosten käyttöä eri tuotteiden kesken (Ylätalo 1987). Rahayksiköllä mitattavaa tuotannon määrää tarvitaan myös siksi, että se antaa tavan laskea yhteen eri tuotteita ja kuvata ne yhdellä muuttujalla. Tuotannon arvo on muutettu kiinteähintaiseksi käyttämällä kasvinviljelytuotteiden hintaindeksiä $(2000=100)$. Tilakohtainen tuotannon määrä oli korkeimmillaan 1990 luvun alussa (Taulukko 1). Aineistoon ei sisällytetty luomutiloja.

Panosten käyttöä kuvataan kolmella muuttujalla, vuotuiskustannuksilla (muuttuvat kustannukset ja ylläpitokustannukset), työllä ja pääomalla. Työtä mitattiin työtunteina, joihin sisällytettiin maatalouden juokseviin töihin kuuluvat tunnit. Pääomaan sisällytettiin koneiden, rakennusten, perusparannusten ja pellon arvo. Pääoman määrästä poistettiin kuluttajahintaindeksillä inflaation vaikutus. Vuotuiskustannus muutettiin vuosien välillä vertailukelpoiseksi maatalouden tuotantopanosten hintaindeksillä. Molemmissa panosten indeksikorjauksissa käytettiin perusvuonna vuotta 2000, samalla tavalla kuin tuotannon määrän indeksikorjauksessakin. Pääoman määrän väheneminen 1980-luvun lopun jälkeen on selitettävissä sillä, että tilakoon kasvu on perustunut pääosin lisääntyneeseen pellonvuokraukseen (Iltanen 1999). Vuokrat sisällytettiin vuotuiskustannukseen. Toisaalta ylläpitoinvestoinnit eivät ole kattaneet viime vuosina koneiden ja rakennusten kulumista. Viljelytöihin kuluneen työn määrä on laskenut tarkasteluajanjaksona selvästi, vaikka tilakoko on kasvanut. 
Taulukko 1. Aineisto.

\begin{tabular}{|c|c|c|c|c|c|c|c|c|c|c|c|c|c|c|c|c|c|c|c|c|c|}
\hline \multirow[b]{2}{*}{$\begin{array}{l}\text { Vuo- } \\
\text { si }\end{array}$} & \multirow[b]{2}{*}{$\mathrm{N}$} & \multicolumn{4}{|c|}{$\begin{array}{l}\text { Viljelyssä oleva peltoala } \\
\text { (ha) }\end{array}$} & \multicolumn{4}{|c|}{$\begin{array}{l}\text { Tuotannon arvo tiloittain vuoden } \\
2000 \text { hinnoin }(€)\end{array}$} & \multicolumn{4}{|c|}{$\begin{array}{l}\text { Vuotuiskustannukset tiloittain } \\
\text { vuoden } 2000 \text { hinnoin }(€)\end{array}$} & \multicolumn{4}{|c|}{$\begin{array}{l}\text { Pääoman määrä tiloittain vuoden } 2000 \\
\text { rahan arvoon muutettuna (€) }\end{array}$} & \multicolumn{4}{|c|}{$\begin{array}{l}\text { Maatalouden juoksevat työt } \\
\text { (tuntia) tiloittain }\end{array}$} \\
\hline & & $\begin{array}{l}\text { Keski- } \\
\text { arvo }\end{array}$ & Q1 & $\begin{array}{l}\text { me- } \\
\text { diaa- } \\
\text { ni }\end{array}$ & Q3 & $\begin{array}{l}\text { Keski- } \\
\text { arvo }\end{array}$ & Q1 & $\begin{array}{l}\text { medi- } \\
\text { aani }\end{array}$ & Q3 & $\begin{array}{l}\text { Keski- } \\
\text { arvo }\end{array}$ & Q1 & $\begin{array}{l}\text { medi- } \\
\text { aani }\end{array}$ & Q3 & $\begin{array}{l}\text { Keski- } \\
\text { arvo }\end{array}$ & Q1 & mediaani & Q3 & $\begin{array}{l}\text { Keski- } \\
\text { arvo }\end{array}$ & Q1 & $\begin{array}{l}\text { medi- } \\
\text { aani }\end{array}$ & Q3 \\
\hline 1976 & 70 & 35,94 & 21,02 & 30,60 & 47,19 & 6909 & 8485 & 13600 & 22566 & 9792 & 10025 & & 24801 & 202849 & 115545 & 190269 & 273889 & 1742 & 1076 & 1667 & 2334 \\
\hline 1977 & 73 & & 21,93 & 30,61 & 48,01 & 4339 & 088 & 201 & 3447 & 752 & 0989 & & 27417 & & & & 265911 & & 935 & 1583 & 2227 \\
\hline 1978 & 69 & 7,13 & 22,50 & 34,86 & 46,90 & 3858 & 7482 & 1009 & 18211 & & & & 27472 & & & & 266268 & & 890 & & 2268 \\
\hline 1979 & 70 & ,04 & 24,20 & 32,44 & 48,00 & 13841 & 8046 & 12035 & 18120 & 9300 & 117 & 157 & 249 & 207 & 1290 & 185936 & 275611 & & 1062 & 1622 & 2160 \\
\hline 1980 & 76 & 5,59 & 21,56 & 29,99 & 45,36 & 14600 & 72 & 12379 & 19945 & 7409 & 04 & & 21826 & 90 & & & 237266 & & 979 & & 2065 \\
\hline 1981 & 85 & 6,23 & 23,75 & 30,14 & 45,32 & 12449 & 6873 & 10297 & 15040 & 7650 & 10 & & 20964 & & 048 & & 237557 & & 1065 & & 2095 \\
\hline 1982 & 96 & 36,36 & 21,32 & 31,45 & 45,87 & 15448 & 7964 & 12864 & 20500 & 8940 & 11096 & 16225 & 24191 & 2047 & 119360 & & 252902 & & 911 & 1437 & 2180 \\
\hline 1983 & 102 & 6,74 & 21,54 & 31,87 & 49,40 & 18988 & 10070 & 16512 & 25738 & 0211 & & & 26126 & & & & 307160 & & 904 & & 1951 \\
\hline 1984 & 104 & 6,79 & 21,42 & 31,87 & 49,55 & 18042 & 9162 & 15636 & 24266 & & & & 28 & & & & 324900 & & 987 & & 2230 \\
\hline 1985 & 127 & 35,67 & 20,50 & 31,15 & 47,00 & 16393 & 84 & 12960 & 22370 & 22287 & 11874 & 18595 & 27289 & & 125269 & 821 & 313039 & & 861 & 14 & 2048 \\
\hline 1986 & 127 & 36,59 & 21,30 & 30,05 & 50,92 & 16934 & & 13860 & 22692 & 24272 & 137 & & 30871 & & & & 348345 & & 925 & & 2131 \\
\hline 1987 & 124 & 37,33 & 22,01 & 34,25 & 48,84 & 14443 & 7061 & 11376 & 20346 & 28798 & 14478 & & 41771 & & 877 & & 349855 & & 959 & 13 & 2013 \\
\hline 1988 & 136 & 37,25 & 22,87 & 35,89 & 49,77 & 13869 & 7111 & 11429 & 20161 & 25088 & 14279 & & 32830 & & 138868 & & 308570 & & 898 & 1294 & 1749 \\
\hline 1989 & 141 & 36,33 & 22,30 & 34,09 & 48,02 & 19529 & 10971 & 18071 & 26641 & 2633 & 12799 & & 30470 & & & & 312059 & & 844 & 1321 & 1872 \\
\hline 1990 & 136 & 37,60 & 24,62 & 34,85 & 48,67 & 21890 & 11885 & 19654 & 29261 & 4665 & 14348 & & 31860 & & 136015 & & 300979 & & 817 & & 1742 \\
\hline 1991 & 132 & 7,26 & 24,57 & 35,00 & 47,80 & 20311 & 9943 & 17362 & 27264 & 7138 & 156 & & 34300 & & & & 282539 & & 749 & & 1774 \\
\hline 1992 & 125 & 38,78 & 25,43 & 37,51 & 49,70 & 18309 & 11320 & 17036 & 24953 & 25088 & 15316 & & 33115 & & 248 & 344 & 274794 & & 771 & 1213 & 1683 \\
\hline 1993 & 125 & 40,34 & 25,67 & 38,10 & 51,00 & 18769 & 9915 & 17865 & 24617 & 23629 & 14846 & 21182 & 31741 & 203621 & 124587 & 179627 & 273922 & 1396 & 870 & 1235 & 1691 \\
\hline 1994 & 112 & 42,44 & 26,50 & 38,36 & 54,26 & 21913 & 10629 & 18959 & 30251 & 27522 & 13996 & 24759 & 33717 & 203270 & 117478 & 172361 & 267047 & & 783 & 1139 & 1658 \\
\hline 1995 & 88 & 43,81 & 26,95 & 38,65 & 59,08 & 21294 & 12178 & 18075 & 26508 & 3632 & 13708 & 20759 & 31644 & 241031 & 137233 & 202913 & 328166 & & 891 & 1190 & 1810 \\
\hline 1996 & 81 & 47,11 & 29,10 & 40,97 & 62,03 & 20338 & 11484 & 17445 & 28355 & 24659 & 15161 & 21821 & 32657 & & 150231 & 220241 & 334960 & & 880 & 1345 & 1833 \\
\hline 1997 & 85 & 45,12 & 26,40 & 40,20 & 61,35 & 17539 & 10423 & 16421 & 22321 & 23606 & 15261 & & 29918 & & & & 326252 & & 792 & 1200 & 1770 \\
\hline 1998 & 87 & 45,16 & 26,08 & 39,33 & 61,50 & 16241 & 6578 & 12706 & 21880 & 22196 & 11811 & 18100 & 29667 & 216551 & 121857 & 187989 & 298296 & 1329 & 676 & 1095 & 1878 \\
\hline 1999 & 80 & 45,84 & 26,90 & 38,94 & 66,54 & 13511 & 5594 & 12442 & 16574 & 22639 & 13058 & 19149 & 28954 & 209321 & 118526 & 181376 & 273911 & 1189 & 700 & 1026 & 1622 \\
\hline 2000 & 95 & 44,51 & 27,00 & 39,51 & 61,24 & 18779 & 7681 & 15539 & 25767 & 20748 & 11423 & 18738 & 25381 & 186175 & 96205 & 162140 & 267340 & 1154 & 605 & 994 & 1703 \\
\hline 2001 & 94 & 44,11 & 26,04 & 37,75 & 63,20 & 16926 & 6167 & 13524 & 24599 & 20901 & 11206 & 18155 & 27581 & 181241 & 104749 & 153211 & 254747 & 1153 & 603 & 1012 & 1631 \\
\hline 2002 & 97 & 45,88 & 27,05 & 39,81 & 66,13 & 18480 & 7255 & 15411 & 24683 & 21282 & & & 27061 & & 108273 & & 251281 & & 614 & 1107 & 1592 \\
\hline 2003 & 107 & 45,04 & 26,04 & 39,65 & 64,62 & 16850 & 6829 & 12951 & 24498 & 19843 & 10970 & 17095 & 25557 & 185846 & 102886 & 152810 & 265085 & 1050 & 540 & 972 & 1455 \\
\hline
\end{tabular}

Q1= alakvartaali (korkeintaan 25 \% havainnoista on Q1:stä pienempi.

mediaani (korkeintaan 50 \% havainnoista on mediaania pienempiä)

Q3= yläkvartaali (korkeintaan 75 \% havainnoista on Q1:stä pienempi. 
Tilat jaettiin viiteen ryhmään viljelypinta-alan perusteella (kussakin ryhmässä vuosittain 20 \% tiloista). Koska tuottavuuskehityksestä oltiin kiinnostuneita myös tukialueittain, tilat jaettiin ryhmiin niin, että A ja B tukialue muodostivat kumpikin omat ryhmänsä ja C1-C4 tukialueista muodostettiin yksi ryhmä. Eri ryhmien keskimääräinen tilakoko on esitetty Taulukossa 2.

Taulukko 2. Tilojen koko tutkimusajanjaksona (viljelyssä oleva pinta-ala) eri tutkimusryhmissä.

\begin{tabular}{llllll}
\hline Kokoluokka & Havaintoja & Keskiarvo & Tukialue & Havaintoja & Keskiarvo \\
\hline erittäin pieni & 560 & 16,61 & A & 1042 & 43,44 \\
pieni & 566 & 26,01 & B & 1270 & 39,36 \\
keskikokoinen & 570 & 35,41 & C1-C4 & 532 & 32,54 \\
suuri & 566 & 48,18 & & & \\
erittäin suuri & 582 & 70,58 & & & \\
\hline
\end{tabular}

Tuottavuuskehityksen (TFP) määrittäminen tuotantofunktion avulla

Tässä tutkimuksessa käytetään kahta eri tuotantofunktiota. Molemmat perustuvat yleistettyyn CobbDouglas funktiomuotoon, jossa selittävistä muuttujista käytetään sekä ensimmäisen että toisen asteen termejä. Funktiomuoto ei huomioi muuttujien välisiä yhdysvaikutuksia, minkä vuoksi tekninen kehitys on perusmallissa kaikilla tiloilla sama ja vaihtelee vain vuosittain.

Time Trend (TT) mallissa aikaa kuvaavaa muuttujaa käytetään selittävänä muuttujana muiden selittävien muuttujien tapaan. Aikaa kuvaava muuttuja kuvaa siis tuotannon teknistä muutosta ajan suhteen. TT-malli voidaan kirjoittaa muotoon:

$$
\ln y=\alpha_{0}+\sum_{j} \alpha_{j} \ln x_{j}+\alpha_{t} t+\sum_{j} \chi_{j}\left(\ln x_{j}\right)^{2}+\alpha_{t t} t^{2}
$$

missä y on tuotannon määrä, $\mathrm{x}_{\mathrm{j}}$ :t ovat tuotantopanoksia ja t kuvaa aikaa. Yllä esitetyn tuotantofunktion oletetaan täyttävän tarvittavat symmetrisyys- ja konveksisuusehdot. TT-malli kuvaa tuotantofunktion tasaista siirtymää yli ajan.

General Index (GI) mallissa Baltagin ja Griffin (1988) trendimäinen aikaa kuvaava muuttuja t on korvattu aikaa kuvaavien dymmy- muuttujien vektorilla. GI-mallissa estimoidaan vuosittaisten dummymuuttujien parametriestimaatit $\mathrm{A}(\mathrm{t})$, kun $(\mathrm{t}=1, \ldots, \mathrm{T})$. Tässä tapauksessa vuosi-dummyt kuvaavat hyvin tuotantofunktiossa esiintyvää vuotuista vaihtelua. TT-malli sisältää huomattavasti enemmän rakenteellisia rajoitteita kuin GI-malli. Molempien mallien käyttö on kuitenkin perusteltua, sillä näin tuottavuuskehityksessä ilmiötasolla tapahtuva hidas muutos voidaan suhteuttaa viljanviljelyssä esiintyvään suureen vuotuiseen vaihteluun. GI-malli voidaan kirjoittaa yleistetyn Cobb-Douglas funktiomuodon tapauksessa seuraavasti:

$$
\ln y=\alpha_{0}+\sum_{j} \alpha_{j} \ln x_{j}+\sum_{j} \chi_{j}\left(\ln x_{j}\right)^{2}+A(t) .
$$

Tekninen kehitys (TC) (tuotantofunktion derivaatta ajan suhteen) saadaan TT ja GI malleista seuraavasti:

$$
\begin{aligned}
& T C_{T T 1}=\alpha_{t}+2 \alpha_{t t} t \mathrm{ja} \\
& T C_{G I 1}=\left(A_{t}-A_{t-1}\right)
\end{aligned}
$$

Esitetyistä tuotantofunktioissa (1) ja (2) ei ole aikaa kuvaavien muuttujien ja muiden selittävien muuttujien yhdysvaikutuksia, sillä esimerkiksi mielenkiinnon kohteena olleet tukialuetta kuvaavien dummy-muuttujien ja aikamuuttujan yhdysvaikutukset eivät osoittautuneet tilastollisesti merkitseviksi. Tulokset antavat viitteitä siitä, että tekninen kehitys olisi ollut yhtä nopeaa kaikilla tukialueilla ja tukialueiden väliset tuottavuuskehityserot johtuisivat lähinnä skaalaeroista. Kokoluokittaisten tuottavuuskehityserojen selvittämiseksi edellä esitettyjen tuotantofunktioiden rajoitetta lievennettiin lisäämällä aikamuuttujan ja kokoluokkien välinen yhdysvaikutus. Näin kokoluokkien tuottavuuskehityksen erot johtuvat sekä eroista teknisessä kehityksessä että tuotannon skaalassa. Käytetty tuotantofunktion spesifiointi on aika yleinen ja yksinkertainen, mutta silti riittävän joustava kuvatakseen maataloustuotantoa. 
Tuottavuuskehitys (TFP) voidaan kirjoittaa Kumbhakarin ja Lovellin mukaan (2000) TT-mallin tapauksessa:

$$
T \hat{F} P_{T T}=T C_{T T}+(R T S-1) \sum_{j} \varepsilon_{j} \hat{x}_{j}
$$

missä,

$\varepsilon_{j}=\frac{\partial \ln y}{\partial \ln x_{j}}=\alpha+\sum_{j} \alpha_{j} \ln x_{j} \quad$ ja $\quad R T S=\sum_{j} \varepsilon_{j}$,

ja missä muuttujan päällä oleva "hattu” viittaa muutokseen. GI-mallin perusteella tuottavuuskehitys saadaan vastaavasti korvaamalla $\mathrm{TC}_{\mathrm{TT}} \mathrm{TC}_{\mathrm{GI}}$ :llä. Kaavassa (5) esitetty rakenne paljastaa sen, ettei tekninen kehitys ole sama asia tuottavuuskehityksen kanssa ellei skaalatuotto ole 1.

Tässä tutkimuksessa käytetyistä Time Trend- ja General indeksi-malleista on esitetty lukuisia variaatioita ja laajennuksia (esim. Kumbhakar ym. 1999). Tämä perusmalli soveltuu kuitenkin hyvin suhteellisen homogeenisen aineiston analysointiin.

\section{Tulokset ja tulosten tarkastelu}

GI-mallilla saadaan kuvattua hyvin viljantuotannon tuottavuuden vuotuinen vaihtelu (Taulukko 3). Huonot satovuodet 1987, 1988 ja 1999 sekä toisaalta myös hyvät satovuodet kuten 1983,1989 ja 1990 erottuvat selvästi. Tuotantotekniikan vaihtelu on itseisarvoltaan keskimäärin 12 \% vuodessa. GI-mallilla kuvattava suuri vaihtelu tuotantotekniikassa vuosittain korostaa hyvin suomalaisen viljanviljelyn erityispiirteitä. Tuotanto on huomattavan riippuvainen vuotuisista säävaihteluista. Tuottavuuskehityksen tutkimisen kannalta tämä tarkoittaa sitä, ettei tuottavuuskehitystä voi tarkastella kovin lyhyellä aikasarjalla. Esimerkiksi tarkasteltaessa tuottavuuskehitystä vuosien 1995 ja 1999 perusteella näyttäisi siltä, että tuottavuuden taso (GI) olisi laskenut keskimäärin 11 \% vuodessa.

TT-mallin kaltaisella tarkastelulla pystytään tasoittamaan aineistossa esiintyvää vaihtelua ja saamaan parempi kuva pitkän aikavälin muutoksesta. TT-mallin perusteella tuottavuuden taso oli vuonna 2003 noin 9,7 \% korkeampi kuin vuonna 1977. Aikaa kuvaava trendimuuttuja oli mallissa tilastollisesti merkitsevä, joten teknistä muutosta voidaan pitää ainakin tilastollisessa mielessä merkitsevänä. Kuitenkin verrattaessa TT-mallilla kuvattua tuottavuuden tason kokonaismuutosta vuosina 1997-2003 (9,7 \%) keskimääräiseen vuotuiseen vaihteluun GI-mallissa (12 \%), voidaan todeta, ettei tuottavuuden tason kokonaismuutos ole kovin suuri. Muutos voi silti olla taloudellisesti merkittävä, sillä se tarkoittaa sitä, että vuonna 2003 viljanviljelyssä saatiin samalla panosmäärällä aikaan 9,7 \% enemmän tuotantoa kuin vuonna 1977. Jos muutosta tarkastellaan 27 vuoden aikaperspektiivissä, tarkoittaa se sitä, että viljatilojen tuottavuus on noussut keskimäärin 0,36 \% vuodessa.

Tuottavuuskehitys on pysähtynyt EU-aikana. TT-mallin perusteella tuottavuuden taso oli vuosina 1995 ja 2003 lähes sama. GI-mallin tulokset puolestaan osoittavat, ettei vuoden 1994 tuottavuuden tasoon ole päästy kuin vuonna 1995.

Tukialueittain tuottavuuskehityksessä on vain pieniä eroja, jotka johtuvat pelkästään skaalaeroista. Sen sijaan kokoluokittain tarkasteltuna tekninen kehitys on ollut tilastollisesti merkitsevästi erilaista erikokoisilla tiloilla ${ }^{1}$ ja tästä johtuen tuottavuuskehityskin on ollut erilaista (Kuva 1). Isojen tilojen tuottavuuskehitys on ollut EU-aikana nopeampaa kuin pienten tilojen.

1 Tilakokoluokan dummy-muuttujan ja aika-muuttujan välinen yhdysvaikutus on

merkitsevä. 
Taulukko 3. Tuottavuuskehityksen jako komponentteihin sekä tuottavuuden vuotuinen muutos ja taso TT- ja GImallien perusteella.

\begin{tabular}{|c|c|c|c|c|c|c|c|c|}
\hline \multirow{3}{*}{ Vuosi } & \multicolumn{4}{|c|}{ Tuottavuuskehityksen osat } & & & \multirow{2}{*}{\multicolumn{2}{|c|}{ Tuottavuuden taso }} \\
\hline & \multicolumn{2}{|c|}{ Tekninen muutos } & \multicolumn{2}{|c|}{ Skaalan vaikutus } & \multicolumn{2}{|c|}{$\begin{array}{c}\text { Tuottavuuden } \\
\text { vuosimuutos }\end{array}$} & & \\
\hline & TT & GI & TT & GI & TT & GI & TT & GI \\
\hline 1976 & 0,014 & 0,000 & & & & & & \\
\hline 1977 & 0,013 & $-0,226$ & $-0,009$ & $-0,007$ & 0,005 & $-0,233$ & 1,000 & 1,000 \\
\hline 1978 & 0,013 & $-0,014$ & 0,006 & 0,005 & 0,019 & $-0,009$ & 1,019 & 0,991 \\
\hline 1979 & 0,012 & 0,058 & 0,001 & 0,001 & 0,013 & 0,059 & 1,032 & 1,049 \\
\hline 1980 & 0,012 & 0,107 & $-0,002$ & $-0,002$ & 0,010 & 0,105 & 1,043 & 1,160 \\
\hline 1981 & 0,011 & $-0,168$ & $-0,013$ & $-0,012$ & $-0,002$ & $-0,180$ & 1,040 & 0,951 \\
\hline 1982 & 0,010 & 0,169 & $-0,016$ & $-0,014$ & $-0,006$ & 0,155 & 1,034 & 1,098 \\
\hline 1983 & 0,010 & 0,150 & $-0,012$ & $-0,009$ & $-0,002$ & 0,141 & 1,032 & 1,253 \\
\hline 1984 & 0,009 & $-0,110$ & $-0,006$ & $-0,004$ & 0,003 & $-0,114$ & 1,035 & 1,110 \\
\hline 1985 & 0,009 & $-0,103$ & $-0,022$ & $-0,016$ & $-0,013$ & $-0,120$ & 1,022 & 0,977 \\
\hline 1986 & 0,008 & $-0,026$ & $-0,006$ & $-0,004$ & 0,002 & $-0,030$ & 1,024 & 0,948 \\
\hline 1987 & 0,007 & $-0,252$ & $-0,005$ & $-0,004$ & 0,002 & $-0,256$ & 1,026 & 0,705 \\
\hline 1988 & 0,007 & 0,071 & $-0,005$ & $-0,003$ & 0,002 & 0,067 & 1,028 & 0,752 \\
\hline 1989 & 0,006 & 0,402 & 0,001 & 0,001 & 0,007 & 0,403 & 1,035 & 1,056 \\
\hline 1990 & 0,006 & 0,084 & $-0,001$ & $-0,001$ & 0,005 & 0,083 & 1,040 & 1,143 \\
\hline 1991 & 0,005 & $-0,126$ & 0,001 & 0,001 & 0,006 & $-0,125$ & 1,047 & 1,000 \\
\hline 1992 & 0,005 & $-0,029$ & 0,007 & 0,005 & 0,011 & $-0,024$ & 1,058 & 0,976 \\
\hline 1993 & 0,004 & 0,051 & 0,000 & 0,000 & 0,004 & 0,051 & 1,062 & 1,026 \\
\hline 1994 & 0,003 & 0,073 & 0,003 & 0,002 & 0,006 & 0,076 & 1,069 & 1,104 \\
\hline 1995 & 0,003 & 0,003 & 0,030 & 0,021 & 0,034 & 0,024 & 1,105 & 1,131 \\
\hline 1996 & 0,002 & $-0,089$ & 0,003 & 0,002 & 0,005 & $-0,088$ & 1,111 & 1,031 \\
\hline 1997 & 0,002 & $-0,088$ & 0,000 & 0,000 & 0,001 & $-0,088$ & 1,112 & 0,940 \\
\hline 1998 & 0,001 & $-0,118$ & 0,000 & 0,000 & 0,002 & $-0,118$ & 1,114 & 0,829 \\
\hline 1999 & 0,000 & $-0,152$ & 0,007 & 0,006 & 0,008 & $-0,147$ & 1,123 & 0,707 \\
\hline 2000 & 0,000 & 0,420 & $-0,010$ & $-0,009$ & $-0,010$ & 0,411 & 1,112 & 0,998 \\
\hline 2001 & $-0,001$ & $-0,144$ & 0,001 & 0,001 & 0,001 & $-0,143$ & 1,113 & 0,855 \\
\hline 2002 & $-0,001$ & 0,065 & $-0,005$ & $-0,005$ & $-0,007$ & 0,060 & 1,105 & 0,907 \\
\hline 2003 & $-0,002$ & $-0,043$ & $-0,005$ & $-0,005$ & $-0,007$ & $-0,048$ & 1,097 & 0,863 \\
\hline
\end{tabular}

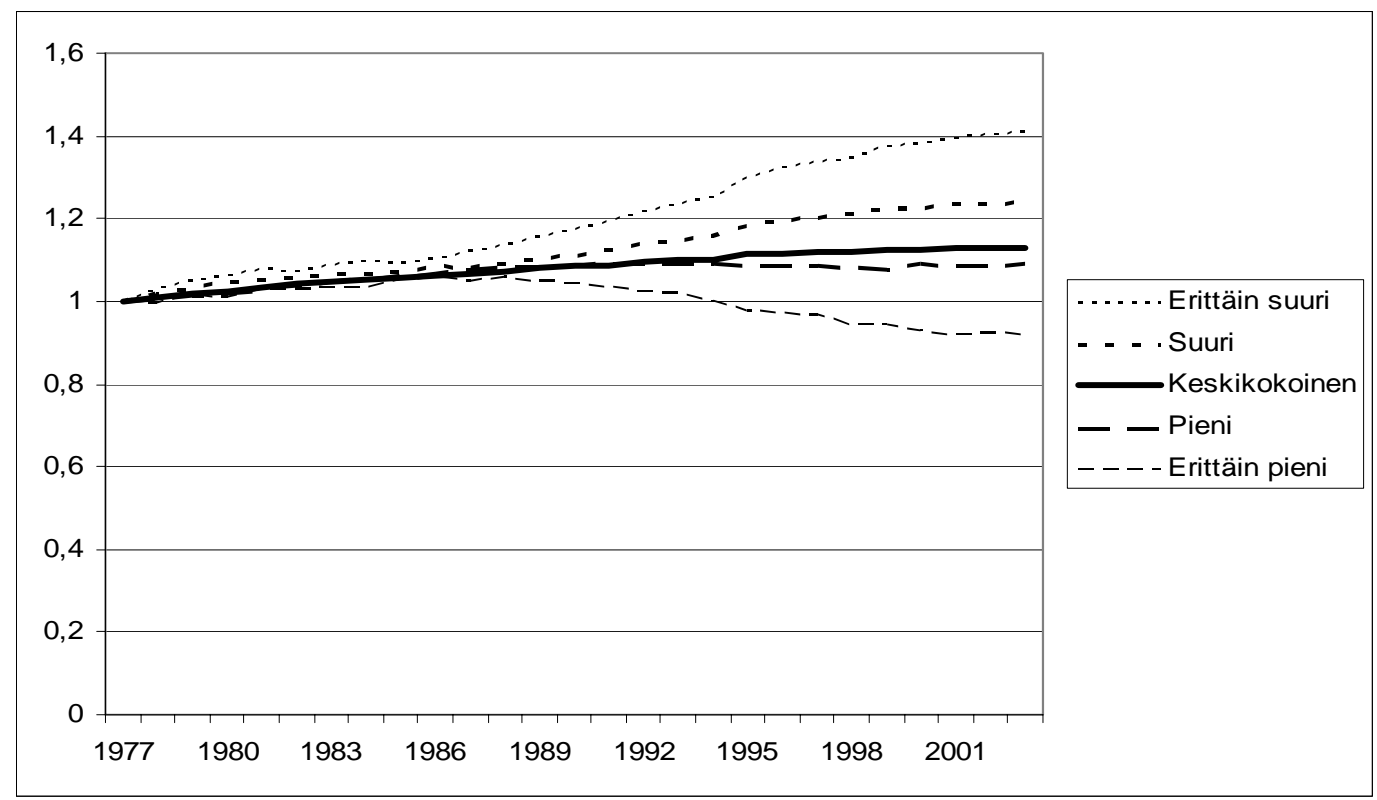

Kuva 1. Tuottavuuskehitys vuosina 1977-2003 tilakokoluokittain (Time Trend-malli). 


\section{Johtopäätökset}

Tässä tutkimuksessa käytettiin kahta eri lähestymistapaa, Time Trend-mallia (TT) ja General Index-mallia (GI) tuottavuuskehityksen mittaamiseen. Molemmat menetelmät antavat hyvin informatiivisia tuloksia. Niillä tuottavuuskehityksestä saatava kuva on kuitenkin varsin erilainen. TT-malli kuvaa paremmin pitkän aikavälin trendimäistä muutosta, kun taas GI-malli tuo esiin tuottavuudessa esiintyvän vuotuisen vaihtelun. Tulokset vahvistavat sitä käsitystä, ettei suomalaisten viljatilojen tuottavuuskehityksessä tapahtuneita eroja voida tarkastella lyhyiden aikasarjojen perusteella. Tämä johtuu siitä, että viljantuotannossa panosten käyttöpäätökset tehdään ennen kuin tiedetään, miten ne muuttuvat tuotannoksi. Sääolosuhteista johtuva tuotannon määrän suuri vaihtelu aiheuttaa suurta vaihtelua myös vuotuiseen tuottavuuden tasoon.

Käytetty tutkimusote edustaa perinteistä tuottavuuskehityksen mittaustapaa, eikä se ota huomioon maatalouden ympäristövaikutuksissa tapahtuneita muutoksia. Ympäristötuen ehtoja syytetään usein siitä, ettei tuottavuutta voida nostaa. Tämän tutkimuksen tulokset osoittavat tuottavuuskehityksen olleen melko vaatimatonta (0,55 \% vuodessa) jo ennen 1995 käyttöön otettua ympäristötukijärjestelmää. Keskimääräisellä tasolla hidas tuottavuuskehitys ei siis voi johtua pelkästään ympäristötuen ehtoihin liittyvistä lannoitteiden käyttörajoituksista.

Tuottavuuskehityksessä ei havaittu eroa tukialueiden välillä. Tämä on merkki sikäli onnistuneesta politiikasta, että kannusteet tuottavuuskehityksen nostamiseen ovat olleet yhtä hyvät / huonot maan kaikissa osissa.

Kokoluokittain tarkasteltuna tekninen kehitys on ollut tilastollisesti merkitsevästi erilaista erikokoisilla tiloilla ja tästä johtuen myös tuottavuuskehitys on ollut erilaista erikokoisilla tiloilla. Isojen tilojen tuottavuuskehitys on ollut myös EU-aikana pienten tilojen tuottavuuskehitystä nopeampaa. Rakennekehitys on siksi toimialan kannalta tärkeää, vaikka skaalatuotot eivät keskiarvotasolla poikkeakaan paljoa 1:stä.

\section{Kirjallisuus}

Baltagi, B. \& Griffin, J. 1988. A General Index of Technical Change. Journal of Political Economy. 96:20-41. Iltanen S. 1999. Land leasing and land rents on Finnish bookkeepping farms. Working papers 13/1999. Agricultural Economics Institute Finland.

Kumbhakar S.C.. Heshmati A. \& Hjalmarsson L. 1999. Parametric Approaches to Productivity Measurement: A Comparison Among Alternative Models. Scandinavian Journal of Economics 101:405-424 p.

Kumbhakar S. C. \& Knox Lovell C. A. 2000. Stochastic Frontier Analysis. Cambridge University Press. Myyrä S. 2004. Productivity development in agriculture. In: Niemi. J. \& Ahlstedt. J. (eds.). Finnish Agriculture and Rural Industries 2004. Agrifood Research Finland Economic Research (MTTL). Publications 104a: 94 p.

TIKE 2003. Yearbook of Farm Statistics 2003. Information Centre of the Ministry of Agriculture and Forestry. Helsinki.

Valtioneuvoston maatalouspoliittinen selonteko. Saatavana internetissä osoitteesta: http://www.mmm.fi/tiedoteliitteet/051020_SELONTEKO.pdf

Ylätalo, M. 1987. Maatalouden tuottavuus ja investoinnit. Pellervon taloudellisen tutkimuslaitoksen julkaisuja 8: $94 \mathrm{s.}$ 